\title{
Correction: Long-term outcome after allogeneic hematopoietic stem cell transplantation for Shwachman-Diamond syndrome: a retrospective analysis and a review of the literature by the Severe Aplastic Anemia Working Party of the European Society for Blood and Marrow Transplantation (SAAWP-EBMT)
}

Simone Cesaro - Marta Pillon - Martin Sauer - Frans Smiers - Maura Faraci ( Cristina Diaz de Heredia Robert Wynn • Johann Greil - Franco Locatelli • Paul Veys • Anne Uyttebroeck • Per Ljungman (1) - Patrice Chevalier • Marc Ansari • Isabel Badell • Tayfun Güngör (1) - Rahuman Salim • Johanna Tischer • Cristina Tecchio - Nigel Russell • Alicja Chybicka - Jan Styczynski (iD - Gergely Krivan - Owen Smith - Jerry Stein - Boris Afanasyev · Cécile Pochon • Maria Cristina Menconi · Paul Bosman · Margherita Mauro · Gloria Tridello · Regis Peffault de Latour · Carlo Dufour

Published online: 9 April 2020

(c) The Author(s), under exclusive licence to Springer Nature Limited 2020

Correction to: Bone Marrow Transplantation https://doi.org/10.1038/s41409-020-0863-z published online 19 March 2020
The original version of this article contained error in the spelling of the author Jan Styczynski, which was incorrectly given as Jan Styzynski.

This has now been corrected in both the PDF and HTML versions of the article. 